\title{
Occurrence of Vibrio cholerae in Some Households Engaged in Livestock Farming in Some Parts of Zaria, Nigeria
}

\author{
Grace Onyukwo Abakpa*, Veronica Jallath Umoh, Joseph Baba Ameh \\ Department of Microbiology, Ahmadu Bello University, Zaria, Nigeria \\ Email: graceabakpa2001@yahoo.com
}

Received October 15, 2012; revised November 17, 2012; accepted December 20, 2012

\begin{abstract}
The study was designed to determine the presence of Vibrio cholerae from the environment in close proximity with livestock in Zaria, Kaduna state. Three hundred and thirty six environmental samples comprising soil, water, manure and vegetables were collected from some selected households in Zaria covering Zaria city, Sabo and Samaru from April to October 2006 and analyzed for the presence of Vibrio cholerae, one of the etiologic agent of gastroenteritis. Twelve Vibrios exhibiting characteristics of Vibrio cholerae were identified using biochemical techniques. Serological identification confirmed $5(41.7 \%)$ of these isolates as Vibrio, $1(20 \%)$ as Vibrio serogroup O1, Ogawa biotype. A 0.59\% prevalence was obtained for this pathogen in the study. The $0.59 \%$ isolation rate though low is significant considering it's source being animal, since livestock keeping is a common feature in the study location, with animals living in close proximity to man. This work is therefore imperative. Animals are a point source of contamination of enteric pathogens, therefore extensive management system and proper treatment of animal manure is recommended before its use as fertilizer.
\end{abstract}

Keywords: Vibrio cholerae; Livestock and Animal Manure

\section{Introduction}

The immediate causes of diarrhoeal illnesses or gastroenteritis are often of an infectious nature and involve a variety of pathogenic microorganisms that include; bacteria, parasites and viruses [1]. Cholera is a pandemic diarrhoeal disease that continues to be an important cause of morbidity and mortality worldwide [2]. It is a major cause of illness in the developing world [3]. The World Health Organization reported in 2006 that 236,896 cases of cholera occurred in 52 countries, a 79\% increase over 2005 [4]. It is associated with a clonally related subset of Vibrio cholerae strains, which belong to the family Vibrionaceae. The Vibrionaceae are gram-negative Gammaproteobacteria that occur in temperate to tropical coastal and estuarine marine systems [5]. Vibrio spp occupy a diverse range of ecological niches, including sediments, the water column and in association with organisms as symbionts [6] or pathogens [7]. Vibrio cholerae strains carry $c t x \mathrm{AB}$ (Cholera toxin subunits A and B ), the Vibrio pathogenicity island (VP1) and other choleraassociated genes [8]. In environmental monitoring of cholera, a large number of samples are often required [9]. Epidemic cholera strains cause human illness by expres-

${ }^{*}$ Corresponding author. sion of specific genes that enable $V$. cholerae to exist in the environment long enough to be ingested, overcome host immunity, colonize the intestinal tract and produce cholera toxin in the host [10] although the pathogenic mechanisms by which these enteropathogens cause diarrhoea are not yet well established [11]. To date, practical typing of $V$. cholerae is mainly serological requiring about 200 antisera [12]. Until 1992, only serogroup O1 (out of more than 206 serogroups currently described) was recognized as a cause of cholera. In 1992, a new non- $V$. cholerae strain (subsequently designated $V$. cholerae O139) appeared in India and rapidly spread across much of Asia [13]. In Nigeria, outbreaks of this disease have been occurring with increasing frequency since the first outbreak of cholera in 1991 in Jos, in which Ogawa was the predominant serotype [14]. Reports of one serotype displacing another have been on the increase and the disease has remained endemic with occasional outbreaks in some parts of the country due to lack of good water supply and poor personal and environmental hygiene [14]. Center for Disease Control (CDC) recent Food Net report suggested a continued increase in Vibrio incidences since 2001, pointing to a need for improved prevention measures [15]. Virulence associated factors in V. cholerae isolates from environmental sources are of concern [16]. 
Monitoring existing environmental strains and undertaking detailed studies of how pathogenic strains evolved from them are essential to our understanding of human disease. This study assessed the presence of livestock and their waste as a source of Vibrio spp in the environment.

\section{Materials and Methods}

Study Areas: The study includes households engaged in livestock farming in Samaru and Sabo in Sabon Gari L.G.A and Zaria city in Zaria L.G.A of Kaduna State. Sabon Gari Local government area is a large urban set up situated along longitude $8^{\circ}$ and latitude $9^{\circ}$ and is bounded on the east by Soba L.G.A, west by Giwa L.G.A and north by Sabon Gari L.G.A and on the South by Igabi L.G.A.

Livestock keeping is a common activity in most households in the area with animals such as poultry, cow, goat, sheep and ram found in most households. The semi intensive and intensive livestock management systems are common while the extensive is rear. Most households have wells situated in their residential area from where water for domestic activities, drinking and water for the animal is obtained. However, some households obtain water from stream or river. Among the households visited, some had vegetable gardens and the wastes from the animals are used in these gardens as manure.

\section{Sampling}

Sampling was restricted to households that had livestock within a close proximity. Thirty households were selected for the study. Ten each from Samaru, Sabo and Zaria city. Three households without livestock were used as control; one from each of the areas selected. Households were selected based on the number of livestock (fifty and above) and consent of the household head to allow sample collection during the visit.

Samples were collected during the dry and wet seasons. Water samples were collected according to the procedure recommended by American Public Health Association [17]. Samples were collected from the available water sources in each households visited comprising of water for domestic activities, drinking and watering of animals. Water samples were collected in sterile wide-mouthed, screw-capped $250 \mathrm{ml}$ glass bottle, packed in ice during transportation to the laboratory. Soil/manure samples were aseptically collected using ethanol—sterilized spatula. A $100 \mathrm{~g}$ of sample was collected at designated site at different points, one from the centre and at four different points, on the periphery and mixed together to obtain a representative sample. Vegetables available in the study sites during the study period and which were grown in soils where manure was applied as fertilizer were collected. Using 90\% ethanol sterilized scissors; vegetables were cut into sterile polythene bags.

All samples were transported to the laboratory in sampling coolers with ice packs and analyzed within six hours of sample collection.

Vibrio was isolated from samples using the method of [18]. Samples were pre-enriched in alkaline peptone and incubated at $37^{\circ} \mathrm{C}$ for $24 \mathrm{~h}$. Vibrio was detected by streaking enriched broth on thiosulphate citrate bile salt (TCBS) agar and incubation at $37^{\circ} \mathrm{C}$ for $24 \mathrm{~h}$. Typical Vibrio colonies which appeared yellow were picked and confirmed by Gram staining and use of biochemical tests by conventional methods $[19,20]$. Salt tolerance was determined by growth of the isolates at $37^{\circ} \mathrm{C}$ in peptone broth without $\mathrm{NaCl}$ then supplement with $1 \%$ and $7 \% \mathrm{NaCl}$.

Serological confirmation of $V$. cholerae strains was performed by an agglutination test with polyvalent O1specific antiserum to identify cholera species. The specific monovalent antiserum against Inaba and Ogawa serogroups were used to identify the Vibrio cholerae serogoup $\mathrm{O} 1$.

\section{Results}

Three hundred and thirty six samples were analyzed during the study from April to October 2006. About 104 (30.95\%) samples were collected from Sabo, 107 (31.85\%) from Zaria city and 125 (37.20\%) from Samaru (Table 1).

Table 1. Samples containing pathogens from the various locations studied.

\begin{tabular}{|c|c|c|c|}
\hline Location & $\begin{array}{l}\text { Source of } \\
\text { sample }\end{array}$ & $\begin{array}{c}\text { Total number } \\
\text { of samples }\end{array}$ & $\begin{array}{c}\text { No of samples that } \\
\text { contain pathogens (Vibrio) }\end{array}$ \\
\hline \multirow[t]{4}{*}{ Sabo } & Water & 26 & - \\
\hline & Soil & 22 & - \\
\hline & Manure & 50 & - \\
\hline & Vegetables & 6 & - \\
\hline Sub-total & & 104 & - \\
\hline \multirow[t]{4}{*}{ Samaru } & Water & 25 & - \\
\hline & Soil & 22 & - \\
\hline & Manure & 64 & 1 \\
\hline & Vegetables & 14 & - \\
\hline Sub-total & & 125 & 1 \\
\hline \multirow[t]{4}{*}{ Zaria city } & Water & 25 & - \\
\hline & Soil & 22 & - \\
\hline & Manure & 56 & 1 \\
\hline & Vegetables & 4 & - \\
\hline Sub-total & & 107 & 1 \\
\hline Overall total & & 336 & $2(0.59 \%)$ \\
\hline
\end{tabular}

Key: - = Pathogen not detected from samples. 
Twelve Vibrios exhibiting characteristics of Vibrio cholerae were identified using biochemical techniques. Serological identification confirmed $5(41.7 \%)$ of these isolates Vibrio of which $1(20 \%)$ was of the Inaba biotype. The remaining $3(60 \%)$ exhibited the biochemical characteristics of the Vibrio cholerae serogroup O1 but could not agglutinate in either Ogawa or Inaba antiserum were presumptively grouped as non-agglutinating Vibrio cholerae. Out of the 104 samples collected in Sabo, no Vibrio cholerae was isolated. One out of 125 samples was positive for Vibrio in Samaru and one out of 107 samples from Zaria city.

During the dry season, no Vibrio cholerae isolate was obtained from samples while during the wet season 2 (1.09\%) Vibrio cholerae was obtained (one from Samaru and one from Zaria city). No Vibrio cholerae isolate was detected from Sabo (Table 2).

\section{Discussion}

A prevalence rate of $0.59 \%$ was obtained for Vibrio in the study. In this study, the two Vibrio isolates found are from animal manure showing the significance of these animals as vehicles of transmission of these organisms in households with livestock. This is an agreement with an earlier report that there is the possibility that the human and animal carriers are the main agents for disseminating these organisms in the environment especially in the freshwater ecosystems [21].

Vibrio cholerae serogroup O1 was one of Vibrio serogroups obtained. The presence of this biotype which has been implicated as the agent of the 7th pandemic cholera is of great concern as the Vibrio cholerae serogroup $\mathrm{O} 1$ is known more than other Vibrio species for causing epidemic cholera and survives longer in water and sewage environments [22]. The Vibrio isolates were detected during the rainy season, showing a marked seasonality pattern among the organism. The incidence of cholera is influenced by local factors, such as rainfall and global climatic conditions [23]. The seasonality of cholera epidemic in Nigeria has been identified [24] and the seasonality may be explained by the increase in water during the summer and fall months as recorded in Louisiana gulf coast [25].

Table 2. Seasonal frequency of pathogens (Vibrio) from the various locations.

\begin{tabular}{|c|c|c|c|c|c|}
\hline \multirow{2}{*}{$\begin{array}{l}\text { Samples } \\
\text { by season }\end{array}$} & \multicolumn{3}{|c|}{ Location } & \multirow{2}{*}{ Total } & \multirow{2}{*}{$\begin{array}{c}\text { Isolation frequency of } \\
\text { pathogens }(\%)\end{array}$} \\
\hline & Sabo & Samaru & $\begin{array}{c}\text { Zaria } \\
\text { city }\end{array}$ & & \\
\hline Dry 153 & - & - & - & - & $0(0.00)$ \\
\hline Wet 183 & - & 1 & 1 & 2 & $2(1.09)$ \\
\hline
\end{tabular}

Key: $-=$ pathogen not detected from samples.
The absence of Vibrio in most of the environmental samples analysed is not surprising. It has been postulated that under stress conditions, the Vibrios are converted to a viable but non culturable (VBNC) form that cannot be recovered by standard culture techniques and that such VBNC forms are able to cause infection and can revert to culturable form [26]. It may also have been due to its existence in an unexplained ecological association with aquatic organisms, possibly in VBNC form, until the next epidemic season when environmental factor trigger the dormant bacteria to multiply and lead to cholera outbreaks [27].

The lack of significant difference in the detection of pathogens with location in this study may be due to similarity in geographical conditions and sources of pollution. [28] noted that cattle (animal) grazing on range lands and pastures may account for a significant amount of point source of pollution. Pasturing operations and livestock management contribute to this type of pollution. Since the households under study had the same pollution source, livestock waste, it may be responsible for the lack of significant difference in the detection of pathogens with location.

\section{Recommendation}

Due to the increased cost of inorganic fertilizer and the need for increased crop production, organic farming is a welcome idea but the risk associated with its use should be minimized through treatment before use. Long storage and composting have been reported to be an important measure in reduction of enteric pathogens in manure. The close proximity of livestock to man or his source of water is a high risk factor and should be avoided.

\section{REFERENCES}

[1] M. K. Estes, "Introduction," In: D. Chadwick and J. A. Goode, Eds, Gastroenteritis Viruses. Novartis Foundation Symposium 238, John Wiley and Sons Ltd., New York, 2001, pp. 1-4.

[2] O. C. Stine, L. Tang, A. Aydanian, G. J. Morris and J. A. Johnson, "Genetic Diversity of O-Antigen Biosynthesis Regions in Vibrio cholerae," Applied and Environmental Microbiology, Vol. 77, No. 7, 2011, pp. 2247-2253.

[3] N. Binsztein, M. C. Costagaliola, M. Pichel, V. Jurquiza, F. C. Ramirez, R. Akselman, M. Vacchino, A. Huq and R. Colwell, "Viable but Non Culturable Vibrio cholerae O1 in the Aquatic Environment of Argentina," Applied Environmental Microbiology, Vol. 70, No. 12, 2004, pp. 74817486 .

[4] World Health Organization, "Cholerae," Weekly Epidemiological Records, No. 82, 2006, pp. 273-284.

[5] C. C. Thompson, F. L. Thompson, H. Vandemeulebroecke, B. P. Dawyndt and J. Swings, "Use of rec $A$ as an Alternative Phylogenetic Marker in the Family Vibriona- 
ceae," International Journal of Systematic Evolution Microbiology, No. 54, 2004, pp. 919-924.

[6] E. G. Ruby, M. Urbanowski, J. Campbell, A. Dunn, M. Faini, R. Gunsalus, P. Lostroh, C. Lupp, J. McCann, D. Millikan, A. Schaefer, E. Stabb, A. Stevens, K. Visick, C. Whistler and E. P. Greenberg, "Complete Genome Sequence of Vibrio fischeri: A Symbolic Bacterium with Pathogenic Congeners," Proceedings of National Academy of Science, No. 102, 2005, pp. 3004-3009.

[7] K. Makino, K. Oshima, K. Kurokawa, T. Uda, K. Tagomori, L. Y. Najima, M. Nakano, M. Yamashita, A. Kubota, Y. Kimura, S. Yasunaga, T. Honda, T. Shinagawa, H. M. Hattori and T. Lida, "Genome Sequence of Vibrio parahaemolyticus: A Pathogenic Mechanism Distinct from That of Vibrio cholerae," Lancet, No. 361, 2003, pp. 743749.

[8] M. Dziejman, "Comparative Genome Analysis of Vibrio cholerae: Genes That Correlate with Cholera Endemic and Pandemic Disease," Proceedings of National Academy of Science, Vol. 99, No. 3, 2002, pp. 1556-1561.

[9] D. Wang, X. Xu, X. Deng, C. Chen, B. Li, H. Tan, H. Wang, S. Tang, H. Qiu, J. Chen, B. C. Ke and B. Kan, "Detection of Vibrio cholerae O1 and O139 in Environmental Water Samples by Immunofluorescent-Aggregation Assay," Applied and Environmental Microbiology, No. 76, 2010, pp. 5520-5525.

[10] B. B. Pal, H. K. Khuntia, S. K. Samal, S. K. Kar and B. Patnaik, "Epidemics of Severe Cholera Cause by El Tor Vibrio cholerae O1 Ogawa Possessing the ctxB Gene of the Classical Biotype in Orissa, India," International Journal of Infectious Diseases, Vol. 14, No. 5, 2010, pp. e384e389.

[11] K. B. Prasanta, B. Poulami, K. H. Tapas, T. Ramamurthy, S. Pradipta, M. Mrinmoyee, C. Goutam and C. D. Suresh, "Putative Virulence Traits and Pathogenicity of Vibrio cholerae Non-O1, Non-O139 Isolates from Surface Waters in Kolkata, India," Applied and Environmental Microbiology, Vol. 74, No. 18, 2008, pp. 5635-5644.

[12] Y. Danin-Poleg, L. A. Cohen, H. Gancz, Y. Y. Broza, H. Goldsmidt, E. Malul, L. Valinsky, L. Lerner, M. Broza and Y. Kashi, "Vibrio cholerae Strain Typing and Phylogeny Study Based on Simple Sequence Repeats," Journal of Clinical Microbiology, Vol. 45, No. 3, 2007, pp. 736746.

[13] G. B. Nair, "Spread of Vibrio cholerae O 139 Bengal in India," Journal of Infectious Disease, Vol. 169, No. 5, 1994, pp. 1029-1034.

[14] S. O. Opajobi, Y. T. Kandakai-Olukemi, J. D. Mawak, M. A. Olukemi and C. S. S. Bello, "Vibrio cholerae O1 Infections in Jos, Nigeria," African Journal of Clinical and Experimental Microbiology, Vol. 5, No. 3, 2004, pp. 260264.

[15] Centers for Disease Control and Prevention, "Preliminary FoodNet Data on the Incidence of Infection with Pathogens Transmitted Commonly through Food-10 States, 2009," Morbidity and Mortality Weekly Report, Vol. 59, No. 14, 2010, pp. 418-422.

[16] I. N. G. Rivera, J. Chun, A. Huq, R. B. Sack and R. R.
Colwell, "Genotypes Associated with Virulence in Environmental Isolates of Vibrio cholerae," Applied Environmental Microbiology, Vol. 67, No. 6, 2001, pp. 24212429.

[17] American Public Health Association, "Standard Methods for the Examination of Water and Waste Water," 18th Edition, American Public Health Association, Washington DC, 1992.

[18] M. S. Islam, M. J. Alam and P. K. B. Neogi, "Seasonality and Toxicity of Vibrio cholerae Non-O1 Isolated from Different Components of Pond Ecosystem of Dhaka City, Bangladesh," World Microbiology and Biotechnology, No. 8, 1992, pp. 160-163.

[19] J. G. Collee, A. G. Fraser, B. P. Marmion and A. Simmons and M. Mackie, "Practical Medical Microbiology," 14th Edition, Churchill Livingstone, New York, 2008.

[20] J. J. Farmer and B. R. Davis, "Escherichia coli O157:H7 Associated with Haemorrhagic Colitis," Journal of Clinical Microbiology, No. 22, 1985, pp. 620-625.

[21] T. Popvic, I. Patricia, I. Fields, O. Olsvik, G. Wells, M. Gracia, N. Daniel, J. J. Farmer, A. Cheryl, K. Bopp, T. Nair, J. Shimada and C. Feley, "Molecular Subtyping of Toxigenic Vibrio cholerae O139 Causing Epidemic Cholera in India and Bangladesh," Journal of Infectious Disease, Vol. 171, No. 1, 1995, pp. 122-127.

[22] K. Ohotomo, V. Kobayashi, A. Sumi and N. Ohotomo, "Relationship of Cholera Incidence to El Nino and Solar Activity Elucidated by Time-Series Analysis," Epidemiology and Infection, Vol. 138, No. 1, 2010, pp. 99-107.

[23] "Uptake on Cholera in Nigeria," Nigerian Bulletin of Epidemiology, No. 1, 1991, pp. 22-24.

[24] W. Philip, L. Loise, M. Mcfarland, H. Barbara, N. Peltier, R. Henry, B. Bradford, L. Joy, D. Herndon, F. Stroup, B. Joyce, P. Mathison, A. Blake and A. G. Robert, "Vibrio Gastroenteritis in Louisiana: A Prospective Study among Attendees of a Scientific Congress in New Orleans," Journal of Infectious Diseases, Vol. 160, No. 6, 1989, pp. 978-981.

[25] R. R. Colwell and A. Huq, "Vibrios in the Environment: Viable but Non-Culturable Vibrio cholerae," In: I. K. Waschsuth, P. A. Blake and O. Olsvik, Eds., Vibrio cholerae and cholera: Molecular to Global Perspectives, Washington DC, 1994, pp. 117-133.

[26] J. A. Moore, J. D. Smyth, E. S. Baker, J. R. Miner and D. C. Moffit, "Modeling Bacteria Movement in livestock Manure Systems," Transactions of the American Society of Agricultural Engineers, Vol. 32, No. 3, 1989, pp. 10491053.

[27] W. H. Ewing and B. R. Davis, "Medium and Tests for Differentiation of Enterobacteriaceae," US Department of Health and Human Services, Center for Disease Control, New York, 2010.

[28] O. C. Stine, M. Alam, L. Tang, G. B. Nair, K. Siddique, S. M. Faruque, A. Huq, R. Colwell, B. R. Sack and J. G. Morris, "Seasonal Cholera from Multiple Small Outbreaks, Rural Bangladesh," Emerging Infectious Diseases, Vol. 14, No. 5, 2008, pp. 831-833. 